\title{
Virtual Reality: A Real Treatment Option
}

\author{
By Jack M. Gorman, MD
}

It is the task of physicians to face the cold, hard facts of reality. We cannot always give our patients or their families good news, make the adverse effects of medications disappear, or convince a managed care formulary to approve a treatment that we think a patient really needs. In this issue of CNS Spectrums, however, we present a series of articles on a topic that may seem like an escape from reality.

If you have visited Disney World in Orlando, Florida, or other amusement parks across the world, you have probably encountered virtual reality (VR). These are "rides" in which you sit still but feel as if you are rocketing into space or sailing across the ocean. Some people find these rides physically unpleasant in the same manner as roller coasters, even though the body itself is hardly made to move. The effects of VR are compelling and fun, but it may come as quite a surprise that they can also have medical utility.

I have always wondered how a behavioral psychologist would approach a patient who is afraid of flying. Graded in vivo exposure is the preferred treatment for most phobias. Therefore, helping someone overcome a fear of heights, the subway, or of insects can be accomplished in an ordinary environment. But therapists cannot commission airplanes in which to do their work with flying phobic patients. Naturally, the field figured out a solution to this seeming obstacle many years ago and introduced flight simulators, similar to those used to train pilots, as a method of desensitizing people with phobic avoidance of flying.

Now we learn that the possibilities for VR are far more extensive. VR can be used to probe brain function during a variety of tasks, to treat psychiatric illnesses, and even to relieve pain. Even though VR has often been the topic of science fiction novels and movies, in which it is sometimes used for nefarious purposes, I suppose that as VR catches on for medical and scientific purposes, there will also come a field of VR ethics to prevent misuse. Various companies will enter the field of making and marketing VR devices; one can only imagine the displays at our national meetings and the suitcases of company representatives visiting doctors' offices.

One of the most fascinating uses of VR reported recently is its combination with the glycine receptor agonist D-cycloserine. Our guest editor this month, Barbara Olasov Rothbaum, $\mathrm{PhD}_{4}$ of Emory University in Atlanta, Georgia, is a cognitive-behavioral therapy specialist who has collaborated with Emory neuroscientists Michael Davis, PhD, and Kerry Ressler, MD, PhD. Their research used Dcycloserine to enhance the effect of VR in the extinction of avoidance in sufferers of acrophobia. This study has attracted a great deal of scientific interest, as well it should, for three reasons. First, it is one of the most dramatic instances in which a medication and a behavioral intervention have been shown to be synergistic in treating an anxiety disorder. Second, it is a prime example of translational neuroscience. The Davis laboratory, in a series of elegant experiments, had previously shown that glycine agonists enhance conditioned fear extinction in laboratory animals. The study is another example of the recent successes in using glutamate neurotransmitter modulators in the treatment of mood and anxiety disorders. Progress in this area was recently reviewed in the October 2005 CNS Spectrums (guest edited by Sanjay Mathew, MD, of Mount Sinai School of Medicine in NewYork City).

Considering the many possibilities of VR for medicine is intriguing and we welcome your comments and letters. Perhaps you can think of an application of VR that has not been thought of or tested yet. Please share your thoughts with us and our international readership. This may be just one way to launch this new year.

This new year, the tenth for CNS Spectrums, brings many changes to the journal, as you may have already noticed. These changes will, among other things, improve overall readability. Your suggestions have been a great asset in this redesign process. Keep them coming.

Dr. Gorman is the editor of this journal, president and psychiatrist-in-chief at McLean Hospital, chair of Partners Psychiatry and Mental Health, and professor of psychiatry at Harvard Medical School. 
The same goes for this month's letter to the editor. H. Stefan Bracha, MD, at the National Center for Post-Traumatic Stress Disorder in Honolulu, Hawaii, and Edward P. Chronicle, PhD, at the University of Hawaii at Manoa, comment on an article by Bernadette $\mathrm{M}$. Cortese, $\mathrm{PhD}$, and $\mathrm{K}$. Luan Phan, MD, from the October 2005 CNS Spectrums (CNS Spectr. 2005;10:820-830), adding to the ongoing discussion that enriches the available data for physicians and augments the exchange between the journal and readers.

To continue this exchange make sure you fill out the Business Reply Card on the cover. This will allow you to continue receiving complimentary copies of CNS Spectrums throughout the new year.

Finally, while I am on the topic of the new year, let me once again thank all of the peer reviewers (listed below), authors, and editorial staff who help make CNS Spectrums possible and successful. Special thanks to our publisher, Darren L. Brodeur, to our co-editors, Eric Hollander, MD, and Joseph Zohar, $M D$, to our acquisition editor, Shoshana Bauminger, and to our deputy senior editor, José R. Ralat. I wish all of you a very happy and productive 2006. CNS

\section{We would like to thank the following peer reviewers who contributed to CNS Spectrums in 2005:}

James L. Abelson, MD, PhD

Jeanne Leventhal Alexander, MD Lars Arendt-Nielsen,

DrMedSci, PhD

Charles E. Argoff, MD

Lesley M. Arnold, MD

David H. Avery, MD

Alan N. Bateson, PhD

Andre Barkhuizen, MD

D. Caroline Blanchard, PhD

Mary C. Blehar, PhD

David M. Brown, MD

Hansruedi Bueler, PhD

Charles K. Burnett, PhD, DrPH

John V. Campo, MD

Louis R. Caplan, MD

Linda L. Carpenter, MD

Glenn Catalano, MD

Christopher Christodoulou, PhD

Lydia Chwastiak, MD, MPH

C. Robert Cloninger, MD

Ray E. Clouse, MD

Philip J Cowen MD, FRCPsych

Christopher L. Cunningham, PhD

M. Cristina Davila, MD

Ahmed Dokmak, MD

Samuel F. Dworkin, DDS, PhD

John M. Eagles, MB, ChB,

MPhil, FRCPsych

Inge-Marie Eigsti, PhD

Ake Elden, MD

Gianni L. Faedda, MD

Edna B. Foa, PhD

Paolo Follesa, PhD

Julian D. Ford, PhD

Ellen W. Freeman, PhD

B. Christopher Frueh, PhD
Volkmar Gieselmann, MD

David L. Ginsberg, MD

Nicholas J. Grahame, PhD

Guy Griebel, PhD

Jason Gold, PhD

Renee D. Goodwin, PhD, MPH

John L. Goudreau, DO, PhD

Sanjay Gupta, MD

John P. Hatch, PhD

Teruo Hayashi, MD, PhD

Pamela Heaton, BSc, PhD

Margaret M. Heitkemper, PhD, RN, FAAN

Cathy M. Helgason, MD

Victoria Hendrick, MD

Wulf Hevers, PhD

Daniel Hicks, MD

J. Dee Higley, PhD

Ying-Jui Ho, PhD

Stefan G. Hofmann, PhD

James I. Hudson, MD, ScD

David S. Husted, MD

Joseph P. Huston, MD

Gordon Irving, MB, BS,

FFA (SA), MSc (Med),

MMed, Diplomate, ABA

Keith $\mathrm{E}$. Isenberg, MD

Bradley Jacobs, MD, MS

Cheryl Jaigobin, MD, FRCP

Dara G. Jamieson, MD

Scott E. Kasner, MD

Deanna L. Kelly, PharmD

Cheryl Koopman, PhD

Susan G. Kornstein, MD

Jeffrey M. Lackner, PsyD

Dawn Langdon, PhD, CPsychol

Younglim Lee, PhD
Jane Leserman, PhD

$\mathrm{Ge} \mathrm{Li}, \mathrm{MD}, \mathrm{PhD}$

Geoffrey Littlejohn, MD

Maria Livanou, PhD

Kate Miriam Loewenthal, PhD

Leslie Lundt, MD

Paul Mackin, MD, PhD, MRCPsych Isaac Marks, MD, FRCPsych

Randall D. Marshall, MD

John D. Matthews, MD

Scott McCullagh, MD, FRCP(C)

Susan R. McGurk, PhD

Roger S. Mclntyre, MD, FRCPC

Lance R. McMahon, PhD,

PPA, Mersch

Stuart Munro, MD

Pradeep J. Nathan, PhD,

MRACI, CChem

Alexander Neumeister, MD

Michael K. Nicholas, PhD

Philip T. Ninan, MD

Richard W. Olsen, PhD

Barbara L. Parry, MD

Timo Partonen, MD, PhD

Mark J. Pellegrino, MD

A. Otto Quartero, MD, PhD

Natalie L. Rasgon, MD, PhD

Sheila A.M. Rauch, PhD

Dawn Reeve, MD, PhD

Fred Reimherr, MD

Rick Richardson, PhD

Elliott Richelson, MD

Michael Rogawski, MD

Daniel M. Rosenbaum, MD

Lori E. Ross, PhD

Sean B. Rourke, PhD

Uwe Rudolph, MD
Bjørn Rishovd Rund, MD, MHA

Andrea Salmaggi, MD

Mary Sano, PhD

William E. Schlenger, PhD

Norman B. Schmidt, PhD

Michael J. Sernyak, MD

George Simpson, MD

Samuel G. Siris, MD

Michael A. Sloan, MD

Brent Solvason, MD, PhD

Poonam Soni, MD

Igor Spigelman, PhD

Margaret Spinelli, MD

B. Hudnall Stamm, PhD

Hans Steiner, MD

John Studd, DSc, MD, FRCOG

M. Elizabeth Sublette, MD, PhD

Neal R. Swerdlow, MD, PhD

Michael E. Thase, MD

Yousef Tizabi, PhD

Abraham Twerski, MD

Robert J. Ursano, MD

Chandan Vaidya, MD

Christine Van Broeckhoven,

$\mathrm{PhD}, \mathrm{DSc}$

Adele C. Viguera, MD

Seeth Vivek, MD

Po W. Wang, MD

Anna Wirz-Justice, PhD

Katherine L. Wisner, MD, MS

Gill. Wolfe, MD

Janet Wozniak, MD

Paul Wright, MD

Peter P. Zandi, PhD

Carlos A. Zarate, Jr., MD

Douglas Zatzick, MD

Robert Zivadinov, MD, PhD 